УДК 635.648:631.5

(C) 2017

Хареба В. В., доктор сільськогосподарських наук, академік Національна академія аграрних наук України

Унучко О. О., аспірант

(науковий керівник - доктор сільськогосподарських наук, академік В. В. Хареба)

Національний університет біоресурсів і природокористування України

\title{
УРОЖАЙНІСТЬ, СЕРЕДНЯ МАСА І КІЛЬКІСТЬ ПЛОДІВ БАМІЇ ЗАЛЕЖНО ВІД СОРТУ ЗА ВИРОЩУВАННЯ В УМОВАХ ПРАВОБЕРЕЖНОГО ЛІСОСТЕПУ УКРАЇНИ
}

\section{Рецензент - доктор сільськогосподарських наук, стариий науковий співробітник І. В. Кузнєцова}

Бамія - не традииійна овочева культура, яка отримала помітне розповсюдження в світі, ия однорічна, тепловимоглива рослина має не тільки харчову иінність, а й використовується, як лікарська рослина, оскільки має у своєму складі вітаміни і поживні речовини. Розглянуто вплив сорту на формування товарних плодів $i$ їх масу та урожайність рослин бамї. Урожайність сортів бамії в середньому за роки досліджень коливалась у межах 9,0-5,7 m/2a. В зоні Правобережного Лісостепу найвищу урожайність формував сорт Юнона - 8,6 m/2а, що перевищувало контроль на $1,1 \mathrm{~m} / 2$, а найнижчий показник урожайність мав сорт Місцевий 1 - 6,0 m/2a, щуо на 1,5 m/га мение ніж у контрольному варіанті.

Ключові слова: бамія, сівба, сорти, продуктивність, урожайність.

Постановка проблеми. Бамія - не традиційна овочева культура, яка отримала помітне розповсюдження в світі. Рослини бамії мають стрижневий добре розвинений слабо розгалужений корінь. Стебло товсте, і залежно від сортотипу має висоту від 0,3 до 2,5 метрів, гілкування слабке - переважно біля основи (2-7 гілок). Гілкування залежить від площі живлення рослин: в загущених посівах стебла майже не гілкуються. Висота стебла залежить від мети вирощування: в разі вирощування на насіння воно нижче, а ніж за регулярного збирання зав'язей. Рослини рідко опушені жорсткими волосками, контакт 3 якими викликає подразнення шкіри. Тому людям $з$ чутливою шкірою під час збирання зав'язі необхідно користуватися рукавичками, зав'язі зрізають ножицями $[3,4]$.

На сучасному етапі розвитку в овочівництві відкритого грунту України особливий інтерес набуває пошук нових, цінних за поживністю та лікувальними властивостями культур, серед яких виділяється бамія Hibiscus esculentus L. Вона не має значного поширення через низку причин, в тому числі: недостатньою вивченістю сортового складу, біології, агротехніки цієї культури, а також відсутність в необхідній кількості насіння кращих в умовах Правобережного Лісостепу сортів, що відповідають вимогам виробників.

На разі вітчизняними і зарубіжними вченими створено низку сортів бамії, проте технологія вирощування іiі у зональному розрізі на жаль ще не розроблена. Тому одним із основних завдань $\epsilon$ підбір кращого сортименту та проведення господарсько-біологічної оцінки бамії в умовах Правобережного Лісостепу України, оскільки раніше це питання в Україні не вивчалося. Отже, представлені результати досліджень є важливими і актуальними для науки і виробництва [5].

Аналіз останніх досліджень і публікацій, у яких започатковано розв'язання проблеми. В 2014-2015 рр. бамія вирощувалась в 40 країнах світу. Загальні об'єми виробництва даної культури становили 5428 тис. тон. Посівні площі становили 833,9 тис. гектарів.

Критерісм оцінки будь-якої технології вирощування культури є врожайність, але при цьому величина іï повинна бути економічно виправданою і енергетично підтвердженою. Підвищення ефективності виробництва можливе за рахунок впровадження високоврожайних адаптивностійких сортів та впровадження нових технологій, 3 метою одержання екологічно чистої овочевої продукції.

Урожайність бамії в світі в 2007 році становила 3,4 т/га, а в 2014-2015 pp. - 4,2 т/га. Найбільша урожайність відмічається в Америці, а найменша - в Африці. В динаміці для всіх континентів характерний ріст урожайності.

Згідно з Д. Дузіаманом (1997) урожайність від 7 до 12 т/га незрілих плодів вважається відмінною.

В дослідженнях індійського вченого Тиварі (1998) з оцінки використання крапельного зрошення в поєднанні з чорною мульчуючою плів- 
кою одержано урожайність плодів 14,6 т/га за вирощування 55 тис. рослин на гектар [6].

Ця культура широко вирощується в південних районах Сполучених Штатів Америки. Провідні штати виробники бамії: Техас, Флорида, Джорджія та Каліфорнія.

У багатьох частинах Бразилії клімат сприятливий для виробництва бамії; вона найбільш розповсюджена в Північно-Східній та ПівденноСхідній частинах країни (Мота та ін., 2000). У штаті Сан- Паулу період найбільшого споживання бамії припадає з січня по квітень.

Основними регіонами - виробниками бамії $\epsilon$ Азія і Африка, а основними країнами - виробниками Індія, Нігерія, Судан, Ірак, Кот-Д'Івуар, Пакістан, Гана, Сгипет, Бенін, Саудівська Аравія. При цьому Судан, Ірак, Кот-Д'Івуар, Пакістан, Бенін почали вирощувати бамію лише в кінці 70-х-початку 90-х рр. (дані ФАО). У динаміці відмічається значне збільшення посівних площ найбільше в Америці [7].

Метою досліджень було визначити продуктивність і урожайність рослин бамії в умовах Правобережного Лісостепу України.

Матеріали і методи досліджень. Дослідження проводили у 2012-2014 pр. на території навчально-наукової виробничої лабораторії «Випробування селекційних досягнень та екологічної оцінки технологій вирощування плодово-ягідних, овочевих, лікарських i квітково-декоративних культур» (м. Київ) в зоні Правобережного Лісостепу на дерново-підзолистих грунтах легкого гранулометричного складу, згідно 3 «Методикою дослідної справи в овочівництві і баштанництві» [2001]. Попередником були рослини родини гарбузові (гарбуз). Вирощування рослин проводили відповідно до рекомендацій дослідної станції «Маяк» Інституту овочівництва і баштанництва НААН. Площа облікової ділянки 10,5 м², повто- рність досліду - чотириразова, розміщення варіантів систематичне [1].

У досліді висівали насіння таких сортів бамії: 1) Сопілка; 2) Діброва (к); 3) Юнона; 4) Зелений бархат; 5) К-2012; 6) Місцевий сорт 1. Результати досліджень оброблені статистично 3 використанням програми AGROSTAT.

Ділянка, на якій проводився дослід, достатньо типова для даного регіону за типом, якістю грунту і рельєфу. Проведений аналіз грунту свідчить про досить однорідне грунтове покриття дослідної ділянки, яке необхідне для забезпечення достатньої точності досліду. Рельєф ділянки рівний. Поблизу ділянки не було лісових смуг, доріг. Місце під дослідом використовувалось однорідно. Обробіток грунту не відрізнявся, а добрива та пестициди вносились однаково на всій площі. Дослідження проводили відповідно до загальноприйнятих національних методик і стандартів.

У період росту рослин проводили ретельний огляд ділянок i підраховували на них густоту стояння рослин. Початок фази росту і розвитку рослин фіксували, коли вона була відмічена у 10 \% рослин на ділянці, масово - $75 \%$.

Біометричні дослідження проводили на типових рослинах бамії у 1 і 3 повтореннях кожного варіанту досліду.

Коефіцієнт фенотипової стабільності Левіса визначали за формулою наведеною у Жученка A. A.: $\mathrm{SFn}=\mathrm{HE} / \mathrm{LE}$, де HE i LE величина ознаки відповідно до максимального рівня, $\mathrm{n}$ - показник тривалості проведення дослідів.

Результати досліджень. Особливо велике значення для сортів має кількість плодів на рослині. В середньому за роки досліджень кількість плодів на різних сортах варіювала в межах від 11,2 до 14,5 шт., і змінювалась залежно від умов року (табл. 1).

\section{1. Характеристика сортів бамії за кількістю плодів на рослині, ит. (2012-2014 рр.)}

\begin{tabular}{|c|c|c|c|c|c|c|}
\hline \multirow[b]{2}{*}{ Сорт } & \multicolumn{4}{|c|}{ Середня кількість плодів на рослині, шт. } & \multirow[b]{2}{*}{$\begin{array}{c}\text { Відхилення } \\
\text { порівняно } 3 \\
\text { контролем, } \pm \%\end{array}$} & \multirow[b]{2}{*}{$\begin{array}{l}\text { Коефіцієнт } \\
\text { стабільності } \\
\text { Левіса }\left(\mathrm{K}_{\mathrm{sf}}\right)\end{array}$} \\
\hline & $2012 \mathrm{p}$. & 2013 p. & $2014 \mathrm{p}$. & $\begin{array}{c}\text { Середнє за } \\
2012- \\
2014 \text { pp. }\end{array}$ & & \\
\hline Юнона & 12,9 & 14,5 & 14,1 & 13,8 & $+6,2$ & 1,12 \\
\hline Діброва (к) & 13,0 & 12,8 & 13,3 & 13,0 & 0 & 1,03 \\
\hline Сопілка & 12,8 & 13,7 & 13,2 & 13,2 & $+1,5$ & 1,07 \\
\hline K-2012 & 13,1 & 13,5 & 13,1 & 13,2 & $+1,6$ & 1,03 \\
\hline $\begin{array}{l}\text { Зелений бар- } \\
\text { хат }\end{array}$ & 12,2 & 12,9 & 12,4 & 12,4 & $-4,6$ & 1,05 \\
\hline $\begin{array}{l}\text { Місцевий сорт } \\
1\end{array}$ & 11,2 & 11,6 & 12,2 & 12,2 & $-6,1$ & 1,08 \\
\hline$H I P_{05}$ & 1,1 & 0,95 & 1,0 & & & \\
\hline
\end{tabular}


СІЛЬСЬКЕ ГОСПОДАРСТВО. РОСЛИННИЦТВО

\section{2. Маса плодів з однієї рослини у досліджуваних сортів бамї̈, г (2012-2014 рр.)}

\begin{tabular}{|c|c|c|c|c|c|c|}
\hline \multirow{2}{*}{ Сорт } & \multicolumn{4}{|c|}{$\begin{array}{c}\text { Маса плодів з рослини за весь період } \\
\text { плодоношення, Г }\end{array}$} & \multirow{2}{*}{$\begin{array}{c}\text { Відхилення } \\
\text { порівняно } 3 \\
\text { контролем, } \\
\pm \%\end{array}$} & \multirow{2}{*}{$\begin{array}{l}\text { Коефіцієнт } \\
\text { стабільності } \\
\text { Левіса }\left(\mathrm{K}_{\mathrm{sf}}\right)\end{array}$} \\
\hline & $2012 \mathrm{p}$. & $2013 \mathrm{p}$. & $2014 \mathrm{p}$. & $\begin{array}{l}\text { Середнє за 2012- } \\
2014 \text { pp. }\end{array}$ & & \\
\hline Юнона & 113,4 & 126 & 120,4 & 119,9 & $+14,7$ & 1,11 \\
\hline Діброва (к) & 102,2 & 107,8 & 103,6 & 104,5 & 0 & 1,05 \\
\hline Сопілка & 109,2 & 116,2 & 112,8 & 112,7 & $+7,8$ & 1,06 \\
\hline K-2012 & 105,9 & 112,3 & 106,4 & 108,2 & $+3,5$ & 1,06 \\
\hline $\begin{array}{l}\text { Зелений бар- } \\
\text { хат }\end{array}$ & 89,6 & 95,2 & 91,0 & 91,3 & $-12,6$ & 1,06 \\
\hline $\begin{array}{l}\text { Місцевий } \\
\text { сорт } 1\end{array}$ & 79,8 & 88,2 & 86,8 & 84,9 & $-18,7$ & 1,10 \\
\hline$H P_{05}$ & 4,1 & 3,8 & 3,9 & - & - & - \\
\hline
\end{tabular}

У середньому за роки досліджень найбільшою кількістю плодів на рослині характеризувались такі сорти: Юнона (13,8 шт.), Сопілка (13,2 шт.) та контрольний сорт Діброва (13,0 шт.). Найменшу кількість плодів сформували сорти К2012 (13,2 шт.), Зелений бархат (12,4 шт.) і Місцевий сорт 1 (12,2 шт.).

Найбільшу кількість плодів рослини бамії формували в 2013 році і вона дорівнювала 14,5 шт. 3 рослини у сорту Юнона, що перевищувало контрольний сорт Діброва на 1,7 шт.

У 2012 році в проведених нами дослідженнях було отримано найменшу кількість плодів 11,2 шт. 3 рослини сорту Місцевий 1.

Виділяючи цінні джерела, які характеризуються високим рівнем того чи іншого елементу структури врожаю, значення має стабільність сорту. Протягом трьох років за показником кількості плодів на рослині найбільш стабільними були сорти: Діброва (контроль), Сопілка, Зелений бархат.

Найбільше (6,2 \%) відхилення порівняно 3 контролем, в середньому за три роки досліджень отримано у сорту Юнона.

Кожного року досліджень сорт Місцевий 1 мав істотно меншу кількість плодів порівняно 3 контрольним сортом Діброва.

Маса плодів за період збирання з рослини, в середньому по всіх сортах, варіювала від 84,9 до 119,9 г (табл. 2). У результаті досліджень найбільш продуктивними сортами були: Юнона $(119,9)$, Сопілка $(112,7)$, К-2012 $(108,2)$ та контрольний сорт Діброва $(104,5)$. Найменш продуктивними, порівняно $з$ контролем, зарекомендували себе сорти Зелений бархат та Місцевий сорт 1 (табл. 2).

По роках ці показники не були однаковими i залежали від умов року. Найменшу масу плодів 3 рослини за період плодоношення мав сорт Місцевий 1 у 2012 році з масою 79,8 г, що було менше, порівняно 3 контролем на 22,4 г. Найбільшим цей показник був у 2013 році у сорту Юнона і дорівнював 126 г з рослини. Сорти Сопілка та К-2012 так само як і сорт Юнона щороку перевищували контроль.

За показником продуктивності найбільш стабільними був контрольний сорт Діброва $\left(\mathrm{K}_{\mathrm{sf}}\right.$ $=1,05)$. Близьким до нього були сорти Сопілка, К-2012 та Зелений бархат 3 показником $\mathrm{K}_{\mathrm{sf}}-$ 1,06. Коефіцієнт стабільності у сортів Юнона та Місцевий сорт 1 знаходився майже на однаковому рівні і дорівнював 1,11 та 1,10 відповідно.

\section{3. Урожсайність товарних плодів бамії залежно від сорту, $\mathrm{m} / 2 a$}

\begin{tabular}{|c|c|c|c|c|c|c|}
\hline \multirow[b]{2}{*}{ Сорт } & \multicolumn{4}{|c|}{ Урожайність плодів } & \multirow[b]{2}{*}{$\begin{array}{l} \pm \text { до конт- } \\
\text { ролю }\end{array}$} & \multirow[b]{2}{*}{$\begin{array}{c}\text { Коефіцієнт стабіль- } \\
\text { ності Левіса }\end{array}$} \\
\hline & $2012 \mathrm{p}$. & $2013 \mathrm{p}$. & $2014 \mathrm{p}$ & $\begin{array}{c}\text { Середнє за } \\
2012-2014 \text { pp. }\end{array}$ & & \\
\hline Юнона & 8,1 & 9,0 & 8,6 & 8,6 & $+1,1$ & 1,11 \\
\hline Діброва (к) & 7,3 & 7,7 & 7,4 & 7,5 & - & 1,05 \\
\hline Сопілка & 7,8 & 8,3 & 8,1 & 8,0 & $+0,5$ & 1,06 \\
\hline K-2012 & 7,6 & 8,1 & 7,6 & 7,8 & $+0,3$ & 1,06 \\
\hline Зелений бархат & 6,4 & 6,8 & 6,5 & 6,6 & $-0,9$ & 1,06 \\
\hline Місцевий сорт 1 & 5,7 & 6,3 & 6,2 & 6,1 & $-1,4$ & 1,10 \\
\hline HIP $_{05}$ & $\mathbf{0 , 6 3}$ & 0,52 & 0,72 & - & - & - \\
\hline
\end{tabular}




\section{СІЛЬСЬКЕ ГОСПОДАРСТВО. РОСЛИННИЦТВО}

Аналізуючи урожайні дані, необхідно зазначити, що в роки проведення досліджень на величину врожаю бамії суттєвий вплив чинив перебіг гідротермічних умов. Найменш сприятливими для росту i розвитку рослин бамії, особливо в критичні періоди, виявились погодні умови 2012 року, за яких урожайність плодів у сорту Юнона не перевищувала 8,1 т/га, що на 0,8 т/га більше, порівняно 3 контролем (табл. 3).

Найбільшу середню урожайність було отримано у сорту Юнона - 8,6 т/га, що перевищувало контрольний варіант на 1,1 т/га.

Сорти Сопілка та К-2012 формували урожайність плодів 8,0 та 7,8 т/га, що на 0,5 та 0,3 т/га відповідно перевищує контроль. У сорту Зелений бархат урожайність зменшилась на 0,9 т/га, порівняно 3 контрольним варіантом і становила 6,6 т/га. Найнижчий показник урожайності 6,1 т/га формувався у сорту Місцевий сорт 1, що на 1,4 т/га менше, порівняно $з$ контролем.

За роки досліджень сорти Юнона та Сопілка істотно перевищували контроль. Постійність досліджуваної ознаки відображає показник стабільності Левіса. Так, найбільш стабільний показник урожайності мали рослини контрольного сорту Діброва $-1,05$. Дещо більшим цей показник був у сортів

\section{БІБЛІОГРАФІЯ}

1. Бондаренко Г. Л. Методика дослідної справи в овочівництві i баштанництві / Г. Л. Бондаренко, К. І. Яковенко. - Х. : Основа, 2001. -369 c.

2. Жуманиязова М. П. Рост, развитие и продуктивность нетрадиционных овощных культур в Узбекистане / М. П. Жуманиязова. - Петрозаводск : Карельский научный центр РАН, 2008. 419 c.

3. Малопоширені овочеві рослини. Ч.1. / [Хареба В. В., Позняк О. В., Унучко О. О., Хареба О. В]. - Вінниця : ФОП Корзун Д. Ю., 2012. $48 \mathrm{c}$.

4. Позняк О.В. Бамія (гібіск їстівний) / О. П. Позняк, М. В. Харицький, А. М. Маленко. - Ніжин : ТОВ «Видавництво «АспектПоліграф», 2007. - 28 с.
Сопілка, К-2012 та Зелений бархат і становив 1,06. Найбільш нестабільним був сорт закордонної селекції Юнона та Місцевий сорт 1 з показниками 1,11 та 1,10 відповідно.

\section{Висновки:}

1. В умовах Правобережного Лісостепу України на дерново-підзолистих грунтах легкого гранулометричного складу, в середньому за роки досліджень, найбільший показник кількості плодів на рослині встановлено у рослин сорту Юнона 13,8 шт., що на 0,8 шт. більше, порівняно 3 контролем.

2. Найвищий показник маси плодів з рослини також встановлено у сорту Юнона, що в свою чергу перевищувало контроль на 15,4 г. Рівень урожайності бамії корелював 3 продуктивністю рослин бамії. Підвищення продуктивності плодів 3 рослини бамії за вирощування сорту Юнона у 2012-2014 рр. сприяло одержанню найвищої урожайності плодів 8,6 т/га, що перевищувало контроль на 1,1 т/га.

3. Зниження маси плодів 3 рослини бамії до 84,9 г, у сорту Місцевий 1, призводило до зменшення урожайності плодів до 6,1 т/га, що на 1,4 т/га менше ніж у контрольному варіанті.

5. Хареба В. В. Технологія вирощування бамії / В. В. Хареба, О. О. Унучко // Плантатор. - К., 2013. - №3 (11). - C. 92-93.

6. Purquerio L. F. Germination and hardseedness of seeds in okra elite lines / L. F. Purquerio, A. A. Lago, F. A. Passos // Hortic. Bras. Brasília. 28(2). - 2010. - 146-151 p.

7. Simonne E. H. Okra production in Florida / E. H. Simonne, W. M. Stall, S. M. Olson, S. E. Webb, S. Zhang // - Chapter 13, 2010. - 157$165 \mathrm{p}$.

8. Mateus R. F. Evaluation of varieties and cultural practices of okra (Abelmoschus esculentus) for production in Massachusetts / R. F. Mateus. - Massachusetts : Department of Plant, Soil and Insect Sciences, 2011. -34 p. 